\title{
A 90-Day Oral Toxicological Evaluation of the Methylurate Purine Alkaloid Theacrine
}

\author{
Amy Clewell, ${ }^{1}$ Gábor Hirka, ${ }^{2}$ Róbert Glávits, ${ }^{2}$ Philip A. Palmer, ${ }^{1}$ John R. Endres, ${ }^{1}$ \\ Timothy S. Murbach, ${ }^{1}$ Tennille Marx, ${ }^{1}$ and Ilona Pasics Szakonyiné ${ }^{2}$
}

${ }^{1}$ AIBMR Life Sciences, Inc., 2800 East Madison Street, Suite 202, Seattle, WA 98112, USA

${ }^{2}$ Toxi-Coop Zrt., Magyar Jakobinusok tere 4/B, Budapest 1122, Hungary

Correspondence should be addressed to Amy Clewell; amy@aibmr.com

Received 19 May 2016; Revised 11 July 2016; Accepted 21 July 2016

Academic Editor: Steven J. Bursian

Copyright (C) 2016 Amy Clewell et al. This is an open access article distributed under the Creative Commons Attribution License, which permits unrestricted use, distribution, and reproduction in any medium, provided the original work is properly cited.

\begin{abstract}
A 90-day repeated-dose oral toxicological evaluation was conducted according to GLP and OECD guidelines on the methylurate purine alkaloid theacrine, which is found naturally in certain plants. Four groups of Hsd.Brl.Han Wistar rats (ten/sex/group) were administered theacrine by gavage doses of 0 (vehicle only), 180,300, and $375 \mathrm{mg} / \mathrm{kg}$ bw/day. Two females and one male in the 300 and $375 \mathrm{mg} / \mathrm{kg}$ bw/day groups, respectively, died during the study. Histological examination revealed centrilobular hepatocellular necrosis as the probable cause of death. In $375 \mathrm{mg} / \mathrm{kg}$ bw/day males, slight reductions in body weight development, food consumption, and feed efficiency, decreased weight of the testes and epididymides and decreased intensity of spermatogenesis in the testes, lack or decreased amount of mature spermatozoa in the epididymides, and decreased amount of prostatic secretions were detected at the end of the three months. At $300 \mathrm{mg} / \mathrm{kg}$ bw/day, slight decreases in the weights of the testes and epididymides, along with decreased intensity of spermatogenesis in the testes, and lack or decreased amount of mature spermatozoa in the epididymides were detected in male animals. The NOAEL was considered to be $180 \mathrm{mg} / \mathrm{kg}$ bw/day, as at this dose there were no toxicologically relevant treatment-related findings in male or female animals.
\end{abstract}

\section{Introduction}

Theacrine (1,3,7,9-tetramethyluric acid) is a methylurate, which is a class of purine alkaloids similar in structure to methylxanthines such as caffeine. Theacrine is often found as a methylated and oxidized metabolite of caffeine in methylxanthine-producing plants [1]. The two prominent theacrine-containing foods in the human diet are the fruits and seeds of Theobroma grandiflorum (cupuaçu) and kucha green tea from the leaves of Camellia kucha (Camellia assamica var. kucha) [2-8]. Kucha tea leaves have historically been consumed in certain regions of China as a tea and "healthy beverage" [9-11]. The theacrine content of expanding buds and young leaves of kucha has been reported as $\sim 2.8 \%$ of dry weight and the content of mature leaves as $\sim 1.3 \%$ $[2,3,11]$. As an estimate of possible exposure to theacrine from kucha tea, if one were to assume 2-3 grams of tea is used per cup at a theacrine content of $2.8 \%$, a cup of tea would contain approximately $56-84 \mathrm{mg}$ of theacrine (equivalent to $0.8-1.2 \mathrm{mg} / \mathrm{kg}$ bw for a $70 \mathrm{~kg}$ person). Radiolabelled experiments show that theacrine is synthesized from caffeine in some plants including kucha $[2,4]$. Levels of theacrine in cupuaçu plant parts are not well-characterized in the literature.

Only limited research, primarily in cell and animal lines, is available to highlight any potential impact theacrine may have when ingested by humans. Preliminary data from a seven-day oral repeated-dose study by Feduccia et al. [12] demonstrated that theacrine increased locomotor activity in rats while an older study showed a potential biphasic dose-response curve with regard to its effects on activity in mice [13]. Mechanistically, theacrine appears to have adenosine receptor antagonist activity [12]. Other reports have highlighted theacrine's potential to exert dopaminergic and other neurochemical activity suggesting dose-dependent 
anti-inflammatory, antifatigue, analgesic, and mood enhancing bioactivity, although studies in humans are lacking [1416].

Theacrine exhibited hepatoprotective effects in a stressinduced liver damage mouse model as well as strong antioxidant capacity in vitro and in vivo $[3,17]$. In opposition to effects typically seen with caffeine $[18,19]$, Feduccia et al. showed that intraperitoneal injections of up to $48 \mathrm{mg} / \mathrm{kg}$ theacrine did not induce sensitization or tolerance of its physiologic effect over the seven-day period of the study [12].

Few studies on the safety of theacrine were found in a comprehensive literature search. Brief results of an acute toxicity study in mice were published in which the authors calculated the $\mathrm{LD}_{50}$ of orally administered theacrine as $810.6 \mathrm{mg} / \mathrm{kg}$ bw (95\% confidence interval 769.5$858.0 \mathrm{mg} / \mathrm{kg} \mathrm{bw}$ ) [14]. Similar to other purine alkaloids, theacrine was reported to induce chromosomal aberrations in onion root tips, in Vicia faba cells treated during the G2 stage of interphase and in Chinese hamster cells [20, 21]. However, no genotoxicity was found in an in vivo mouse micronucleus study at theacrine concentrations up to $325 \mathrm{mg} / \mathrm{kg}$ bw [22].

In contrast to results observed using C. sinensis $(31 \mathrm{~g} / \mathrm{kg}$ caffeine and $0 \mathrm{~g} / \mathrm{kg}$ theacrine), intragastric administration of water extracts of theacrine-containing teas including $C$. assamica var. kucha (3g/kg caffeine and $22 \mathrm{~g} / \mathrm{kg}$ theacrine) did not lead to increases in blood pressure and heart rate in spontaneously hypertensive rats [10]. When rats were given $30 \mathrm{mg} / \mathrm{kg}$ caffeine, theobromine, or theacrine, only the caffeine treatment had a significant effect on cardiovascular parameters [10].

In a human study of 60 healthy men and women, theacrine was given daily (200 or $300 \mathrm{mg}$ ) for eight weeks [23, 24]. The two doses are equivalent to 2.6 and $3.8 \mathrm{mg} / \mathrm{kg}$ bw/day, respectively, for a $78 \mathrm{~kg}$ human (the average weight for male and female subjects in the study). Primary outcomes included fasting clinical safety markers (heart rate, blood pressure, lipid profiles, and hematologic and liver/kidney/immune function biomarkers), all of which fell within normal limits with no group $\times$ time interactions and no differences in side effect profiles as compared to controls. Theacrine was also given to 15 healthy subjects in a randomized double-blinded crossover study $[25,26]$. A single $200 \mathrm{mg}$ dose (or placebo) was administered, and side effect reports, hemodynamics, and biochemical markers of safety were collected over a 3hour postdosing period, with no significant findings noted. Six subjects additionally participated in a separate 7-day open-label repeated-dose study comparing 100, 200, and $400 \mathrm{mg}$ of theacrine, in which no side effects were noted $[25,26]$.

To investigate further the safety of oral consumption of theacrine, in the current work we report the results of a 90 -day repeated-dose oral subchronic toxicity study in the Wistar rat.

\section{Material and Methods}

The 90-day study was conducted according to OECD GLP (ENV/MC/CHEM (98)17; OECD, Paris, 1998) and in compliance with OECD 408 (adopted 21st September 1998; 90-day study) [27] and US FDA Redbook 2000, IV.C.4.a (2003; 90-day study) guidelines [28]. Care and use of study animals were in compliance with the laboratory's Institutional Animal Care and Use Committee, the National Research Council Guide for Care and Use of Laboratory Animals [29], and the principles of the Hungarian Act 2011 CLVIII (modification of Hungarian Act 1998 XXVIII) regulating animal protection.

Synthetic 1,3,7,9-tetramethyluric acid (CAS number $2309-49-1 ; \geq 98 \%$ pure as measured by high performance liquid chromatography (HPLC), proton nuclear magnetic resonance, and liquid chromatography-mass spectrometry methodologies) was supplied as the branded product TeaCrine ${ }^{\circledR}$ for use as the test article by its manufacturer (Compound Solutions, Inc., Carlsbad, CA). TeaCrine is a commercially available white crystalline powder. A 24month stability study on this product was conducted at $25 \pm 2^{\circ} \mathrm{C}$ with $60 \pm 10 \%$ relative humidity under conditions of commercial packaging and the compound remained stable throughout the testing period (data not shown). Batch number 48-KY20141102, which met all commercial specifications for the product (including $\geq 98 \%$ purity, $\leq 1 \%$ loss on drying, $\leq 0.5 \%$ residue on ignition, and commercial limits for heavy metals and microbial counts) was utilized for the study within the two-year shelf-life date. The specific purity level of this batch (per HPLC analysis) was $99.5 \%$.

The dose levels of theacrine utilized in the study were 375,300 , and $180 \mathrm{mg} / \mathrm{kg}$ bw/day. These doses were chosen based on an unpublished 14-day repeated-dose oral toxicity study in Wistar rats that utilized ten animals per group (five rats/sex/group). The highest dose group of $500 \mathrm{mg} / \mathrm{kg}$ bw/day resulted in mortality of 5 of 5 males and 3 of 5 females and tremors in all animals; additionally one male animal died in the $400 \mathrm{mg} / \mathrm{kg}$ bw/day group. Remaining animals in the 400,350 , and $200 \mathrm{mg} / \mathrm{kg}$ bw/day groups survived without toxicological signs, and the NOAEL of the 14-day study was determined to be $350 \mathrm{mg} / \mathrm{kg}$ bw/day. Based on the results of this study and OECD 408 guidelines stating that the highest dose level should be chosen with the aim to induce toxicity but not death or severe suffering, the high dose for the 90day study was selected as $375 \mathrm{mg} / \mathrm{kg}$ bw/day. The guidelines suggest a descending dose sequence aiming to demonstrate any dose-related responses and a NOAEL at the lowest dose level. While the guidelines state that twofold to fourfold intervals are frequently optimal for setting descending dose levels, in this case smaller intervals were utilized due to the narrow dose range in which adverse events appeared in the 14-day study and with an aim to detect the highest NOAEL possible (which a broader interval may have missed) to allow assessment of the margin of safety of doses used in human studies, such as the $200-300 \mathrm{mg}$ per day dose (2.6$3.8 \mathrm{mg} / \mathrm{kg}$ bw/day for a $78 \mathrm{~kg}$ human) used in the study by Taylor et al. [24], which did not result in adverse events or findings in clinical safety markers.

The test article doses were prepared by suspending theacrine in $1 \%$ aqueous methylcellulose to achieve concentrations of 18,30 , and $37.5 \mathrm{mg} / \mathrm{mL}$ in order to provide a constant dosing volume of $10 \mathrm{~mL} / \mathrm{kg}$ bw. Doses were prepared daily by careful weight measurement and administered 
within four hours. The control group received the same volume of $1 \%$ methylcellulose vehicle only.

Male and female SPF Hsd.Brl.Han Wistar rats (ToxiCoop, Budapest, Hungary) were housed individually, with a 12-hour light-dark cycle at $19-25^{\circ} \mathrm{C}$ and $30-70 \%$ relative humidity, in type II polypropylene/polycarbonate cages with Lignocel ${ }^{\circledR}$ certified laboratory wood bedding. Cages were $22 \mathrm{~cm}$ (width) by $32 \mathrm{~cm}$ (length) by $19 \mathrm{~cm}$ (height), and cages and bedding were changed weekly. Animals received ssniff ${ }^{\circledast}$ SM R/M-Z+H complete diet for rats and mice and potable tap water ad libitum. The animals were acclimated for seven days prior to the start of dosing.

At the start of the experimental period, animals were approximately seven weeks old and weighed 206-233g (males) and 131-151 g (females). Eighty male and female rats were stratified by body weight and randomly assigned to four dose groups containing $10 \mathrm{rats} / \mathrm{sex} /$ group. Theacrine was administered by gavage daily each morning at doses of 0 (vehicle-control), 180, 300, or $375 \mathrm{mg} / \mathrm{kg}$ bw/day.

Animals were observed twice daily for morbidity and mortality. General cage-side observations for clinical signs were made on two occasions during the acclimation period and once daily during the dosing period, at approximately the same time each day, after administration of the test article. Detailed clinical observations were conducted once weekly, and a functional observational battery (FOB) was performed during the final week to assess parameters such as general physical condition and behavior, response to handling, sensory reactions to various stimuli, grip strength, and motor activity [30]. Measurements of body weight were conducted twice during the acclimation period, on the first experimental day prior to treatment, twice weekly during weeks $1-4$, once a week during weeks 5-13, and immediately prior to sacrifice. Food intake was determined and food efficiency calculated once weekly. Ophthalmological examination was carried out on all animals prior to the experimental period and prior to study termination in control and high-dose group animals.

After an overnight fast (approximately 16 hours) following final administration of the test article, three blood samples were collected from the retroorbital venous plexus under Isofluran $\mathrm{CP}^{\circledR}$ (CP-Pharma Handelsgesellschaft $\mathrm{GmbH}$, Germany) anesthesia $(0.25 \mathrm{~mL}$ in tripotassium ethylenediaminetetraacetic acid tubes for hematology measurements, $1.0 \mathrm{~mL}$ in sodium citrate tubes for blood coagulation measurements, and $2.5 \mathrm{~mL}$ in serum separator tubes for clinical chemistry measurements) after which the animals were euthanized by exsanguination from the abdominal aorta. Blood samples were analyzed for hematologic [hematocrit (HCT), hemoglobin (HGB), red blood cell (RBC), white blood cell (WBC), white blood cell differential (neutrophils (NEU), lymphocytes (LYM), monocytes (MONO), eosinophils (EOS) and basophils (BASO)), platelet (PLT), mean corpuscular volume (MCV), mean corpuscular hemoglobin $(\mathrm{MCH})$, mean corpuscular hemoglobin concentration (MCHC), and reticulocyte (RET)], blood coagulation (activated partial thromboplastin time and prothrombin time) and clinical chemistry $\left[\operatorname{sodium}\left(\mathrm{Na}^{+}\right)\right.$, potassium $\left(\mathrm{K}^{+}\right)$, glucose (GLUC), cholesterol, urea concentration, creatinine
(CREA), total protein (TPROT), albumin (ALB), alanine aminotransferase (ALT), aspartate aminotransferase (AST), alkaline phosphatase (ALP), gamma glutamyl transferase (GGT), total bilirubin (TBIL), albumin/globulin ratio, bile acids, calcium $\left(\mathrm{Ca}^{++}\right)$, chloride $\left(\mathrm{Cl}^{-}\right)$, and inorganic phosphate $(\mathrm{Pi})]$ parameters. Gross pathological examinations and determinations of selected absolute organ weights (liver, kidneys, adrenals, testes, epididymides, thymus, spleen, brain, heart, uterus with fallopian tubes, ovaries, and thy$\mathrm{roid} /$ parathyroid) were completed and relative organ weights (compared to body and brain weights) were calculated. Full histopathological examinations were conducted on the preserved organs and tissues (adrenals, aorta, bone marrow of the femur, brain (cerebrum, cerebellum, pons, and medulla oblongata), eyes, female mammary gland, gonads (testes with epididymides and ovaries), heart, kidney, large intestines, liver, lungs, submandibular and mesenteric lymph nodes, quadriceps muscle, esophagus, nasal turbinates, pancreas, pituitary, prostate, submandibular salivary glands, sciatic nerve, seminal vesicle, skin, small intestines, spinal cord at three levels, spleen, sternum, stomach, thymus, thyroid and parathyroid, trachea and urinary bladder, and uterus with vagina) of all animals of the control and high-dose groups. The adrenal glands, testes, and epididymides were also processed and examined histologically in all animals of the low- and mid-dose groups on the basis of the macroscopic observations at the necropsy (pale adrenal glands and smaller than normal testes and epididymides).

Statistical analyses were conducted using SPSS PC+ software (SPSS, Inc., Chicago, IL). Bartlett's homogeneity of variance test was used to assess heterogeneity of variance between groups and was followed by a one-way analysis of variance (ANOVA) if no significant heterogeneity was detected. Duncan's Multiple Range test was used to assess the significance of intergroup differences if a positive ANOVA result was obtained. Where significant heterogeneity was detected by Bartlett's test, the Kolmogorov-Smirnov test was performed to examine normally distributed data, and Kruskal-Wallis nonparametric one-way ANOVA, followed by the Mann-Whitney $U$ test for intergroup comparisons of positive results, was used in the case of a nonnormal distribution. A $p$ value of $<0.05$ was considered statistically significant, and statistically significant results were reported at $p<0.05$ and $p<0.01$ levels.

\section{Results and Discussion}

One male at $375 \mathrm{mg} / \mathrm{kg} b w /$ day and two females at $300 \mathrm{mg} / \mathrm{kg} \mathrm{bw} /$ day were found dead on days 42,33 , and 67 , respectively. There were no preceding clinical signs in the dead male and in one of the dead females. The other female exhibited a decrease in activity on the day before death. Necropsy observations of the dead animals revealed dark red liver (all) and lungs (male and one female), smaller than normal testes (male), clotted blood in the thoracic cavity near to the heart (male), cyanotic skin and subcutaneous connective tissue on the lower part of the abdomen (male), empty stomach (both females) and intestines (one female), 
TABLE 1: Summary of necropsy findings.

\begin{tabular}{|c|c|c|c|c|c|c|c|c|c|c|c|}
\hline \multirow{3}{*}{ Organ } & \multirow{3}{*}{ Observations* } & \multicolumn{5}{|c|}{ Males (mg/kg bw/d) } & \multicolumn{5}{|c|}{ Females (mg/kg bw/d) } \\
\hline & & \multirow{2}{*}{ Control } & \multirow{2}{*}{180} & \multirow{2}{*}{300} & \multicolumn{2}{|c|}{375} & \multirow{2}{*}{ Control } & \multirow{2}{*}{180} & \multicolumn{2}{|c|}{300} & \multirow{2}{*}{375} \\
\hline & & & & & Died early & Survivors & & & Died early & Survivors & \\
\hline & $\begin{array}{l}\text { No macroscopic } \\
\text { findings }\end{array}$ & $10 / 10$ & $9 / 10$ & $6 / 10$ & $0 / 1$ & $0 / 9$ & $9 / 10$ & $6 / 10$ & $0 / 2$ & $6 / 8$ & $3 / 10$ \\
\hline Testes & $\begin{array}{c}\text { Smaller than } \\
\text { normal }\end{array}$ & $0 / 10$ & $0 / 10$ & $4 / 10$ & $1 / 1$ & $9 / 9$ & l & l & l & l & I \\
\hline Epididymides & $\begin{array}{c}\text { Smaller than } \\
\text { normal }\end{array}$ & $0 / 10$ & $0 / 10$ & $4 / 10$ & $0 / 1$ & $9 / 9$ & I & I & I & l & l \\
\hline Prostate & $\begin{array}{c}\text { Smaller than } \\
\text { normal }\end{array}$ & $0 / 10$ & $0 / 10$ & $0 / 10$ & $0 / 1$ & $3 / 9$ & l & l & l & l & I \\
\hline \multirow{2}{*}{ Adrenal glands } & Pale & $0 / 10$ & $0 / 10$ & $2 / 10$ & $0 / 1$ & $7 / 9$ & $0 / 10$ & $0 / 10$ & $0 / 2$ & $0 / 8$ & $4 / 10$ \\
\hline & Enlarged & $0 / 10$ & $0 / 10$ & $0 / 10$ & $0 / 1$ & $0 / 9$ & $0 / 10$ & $0 / 10$ & $1 / 2$ & $0 / 8$ & $0 / 10$ \\
\hline Kidney (left side) & $\begin{array}{l}\text { White compact } \\
\text { formation on } \\
\text { the surface }\end{array}$ & $0 / 10$ & $0 / 10$ & $0 / 10$ & $0 / 1$ & $1 / 9$ & $0 / 10$ & $0 / 10$ & $0 / 2$ & $0 / 8$ & $0 / 10$ \\
\hline \multirow{3}{*}{ Skin } & Alopecia & $0 / 10$ & $1 / 10$ & $1 / 10$ & $0 / 1$ & $0 / 9$ & $0 / 10$ & $0 / 10$ & $0 / 2$ & $0 / 8$ & $0 / 10$ \\
\hline & Scar & $0 / 10$ & $0 / 10$ & $1 / 10$ & $0 / 1$ & $2 / 9$ & $0 / 10$ & $0 / 10$ & $0 / 2$ & $0 / 8$ & $0 / 10$ \\
\hline & Cyanotic & $0 / 10$ & $0 / 10$ & $0 / 10$ & $1 / 1$ & $0 / 9$ & $0 / 10$ & $0 / 10$ & $0 / 2$ & $0 / 8$ & $0 / 10$ \\
\hline Liver & Dark red & $0 / 10$ & $0 / 10$ & $0 / 10$ & $1 / 1$ & $0 / 9$ & $0 / 10$ & $0 / 10$ & $2 / 2$ & $0 / 8$ & $0 / 10$ \\
\hline Lungs & Dark red & $0 / 10$ & $0 / 10$ & $0 / 10$ & $1 / 1$ & $0 / 9$ & $0 / 10$ & $0 / 10$ & $1 / 2$ & $0 / 8$ & $0 / 10$ \\
\hline Thoracic cavity & $\begin{array}{l}\text { Clotted blood } \\
\text { near to the heart }\end{array}$ & $0 / 10$ & $0 / 10$ & $0 / 10$ & $1 / 1$ & $0 / 9$ & $0 / 10$ & $0 / 10$ & $0 / 2$ & $0 / 8$ & $0 / 10$ \\
\hline Stomach & Empty & $0 / 10$ & $0 / 10$ & $0 / 10$ & $0 / 1$ & $0 / 9$ & $0 / 10$ & $0 / 10$ & $2 / 2$ & $0 / 8$ & $0 / 10$ \\
\hline Intestines & Empty & $0 / 10$ & $0 / 10$ & $0 / 10$ & $0 / 1$ & $0 / 9$ & $0 / 10$ & $0 / 10$ & $1 / 2$ & $0 / 8$ & $0 / 10$ \\
\hline Uterus & Hydrometra & I & I & I & I & I & $1 / 10$ & $4 / 10$ & $1 / 2$ & $2 / 8$ & $4 / 10$ \\
\hline
\end{tabular}

${ }^{*}$ Number of animals with observations/number of animals examined.

/, not examined; $\mathrm{mg} / \mathrm{kg}$ bw/day, milligrams per kilogram body weight per day.

hydrometra (one female), and enlarged adrenal glands (one female) (Table 1). During histopathological examination centrilobular hepatocellular necrosis was noted in all three animals (Figures 1 and 2). Chemically induced liver injury can lead to lipidosis, necrosis, fibrosis, and proliferation of organelles, hyperplasia of bile ducts or hepatocytes, and neoplasia [31]. Hepatocellular necrosis may be seen in aging and surviving untreated animals as well as those exposed to toxic chemicals. Necrosis may be coagulative in nature and characterized by homogenous eosinophilia and loss of cellular detail. Chemically induced necrosis is often zonal, most frequently centrilobular or periportal. Thus, the test article was considered to have most likely caused the centrilobular necrosis seen in these animals, and it was considered the probable cause of death.

Slight focal alveolar emphysema and congestion in the lungs and liver were also noted in the three dead animals and, along with the macroscopic changes in the lungs, liver, and heart and the cyanotic skin and subcutaneous connective tissue, were considered to have occurred due to circulatory disturbances developed during agony and/or death. Additionally, a decreased amount of spermatozoa in the epididymides and decreased intensity of spermatogenesis (defined by the proportion of tubuli containing mature spermatozoa) in the testes were observed in the male (Table 2).
In surviving animals, the daily cage-side and weekly detailed clinical observations and the FOB revealed no toxicologically relevant findings. A reduced body weight gain was detected in male and female animals in the 300 and $375 \mathrm{mg} / \mathrm{kg}$ bw/day groups and in male animals of the $180 \mathrm{mg} / \mathrm{kg}$ bw/day group between days 0 and 3 (Table 3 ). The reduced body weight gain of male animals in the 300 and $375 \mathrm{mg} / \mathrm{kg}$ bw/day groups resulted in lower mean body weight from day 3 to day 89 (Table 4) and lower mean total body weight gain with respect to controls. However, this reduced mean body weight gain on days 0 to 3 was fully compensated in male animals of the $180 \mathrm{mg} / \mathrm{kg}$ bw/day group and in both female groups ( 300 and $375 \mathrm{mg} / \mathrm{kg}$ bw/day) during the course of the treatment period resulting in no difference in the summarized mean body weight gain in these groups.

During week 1 , food consumption was slightly decreased compared to controls in male and female treated animals in all dose groups and also occurred in male animals at 300 and $375 \mathrm{mg} / \mathrm{kg}$ bw/day on other weeks (Table 5). In accordance with the changes in body weight and food consumption, the mean feed efficiency was decreased in male animals at the 300 and $375 \mathrm{mg} / \mathrm{kg} \mathrm{bw} /$ day dose levels during week 1 and transiently thereafter (Table 6).

No ophthalmologic abnormalities were observed in the control and $375 \mathrm{mg} / \mathrm{kg}$ bw/day groups prior to the start of 


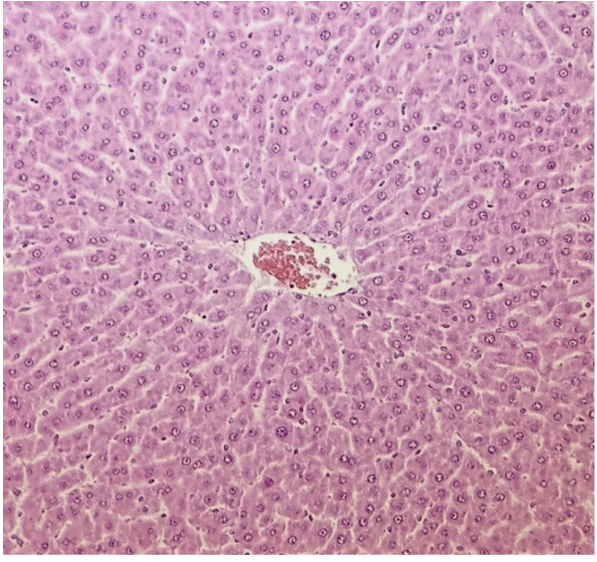

(a)

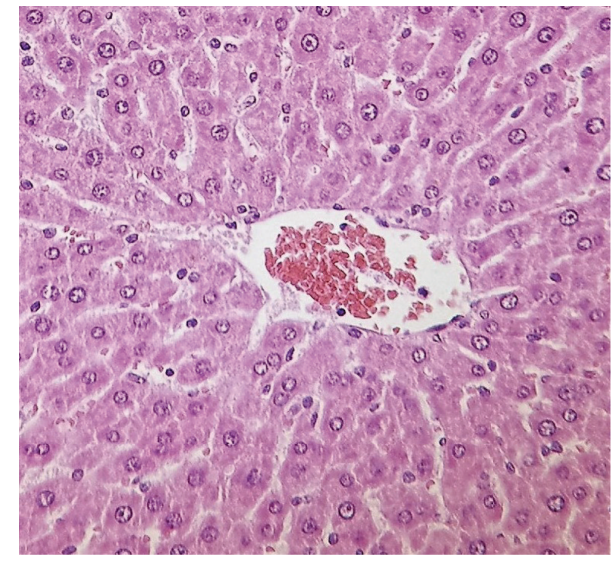

(b)

Figure 1: Intact (normal) hepatocytes around the central vein of a female rat at $375 \mathrm{mg} / \mathrm{kg}$ bw/day at terminal sacrifice. Haematoxylin and eosin staining; magnification 200x (a) and 400x (b).

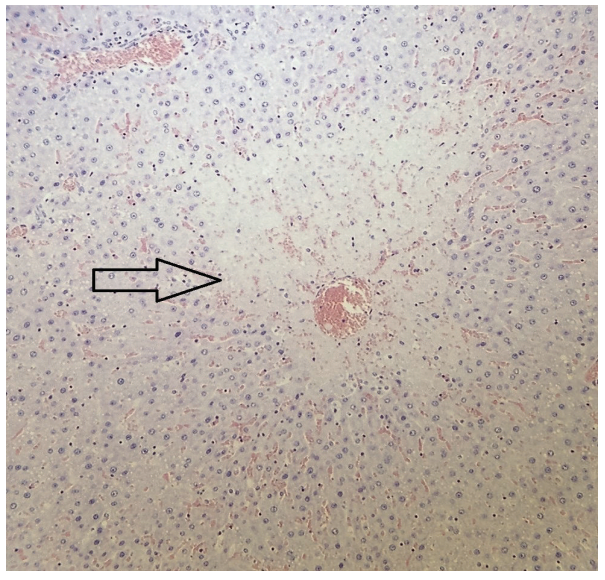

(a)

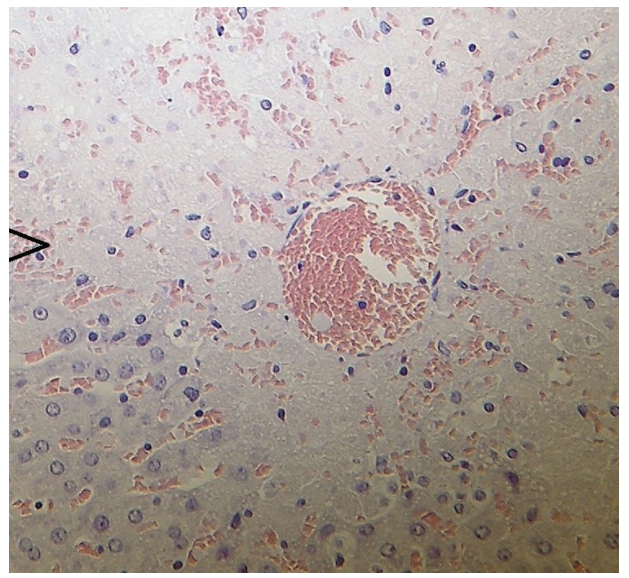

(b)

Figure 2: Centrilobular necrosis (arrows) in the liver of a female rat at $300 \mathrm{mg} / \mathrm{kg}$ bw/day found dead on day 33 . Haematoxylin and eosin staining; magnification 200x (a) and 400x (b).

dosing or at the end of the treatment period (data not shown). Statistically significant differences between treatment and controls were noted in some hematological and clinical chemistry parameters in male and female animals and are shown in Tables 7 and 8, respectively. Statistically significant differences in MCHC and RET values as compared to controls in males and RBC values in both males and females were not clearly dose-dependent and fell well within historical control ranges and were thus not considered toxicologically relevant. EOS values appeared to decrease dose-dependently within historical ranges in both genders; however, decreases in this value are not generally considered biologically relevant. Significant differences in MCV and MCH levels were slight and values remained within historical control ranges in the $180 \mathrm{mg} / \mathrm{kg} \mathrm{bw} /$ day group (and were within or marginal to historical control ranges in the mid- and high-dose groups). Related hematological parameters such as HGB and HCT were not different than controls, and no hematologically related organ pathologies were noted. Thus the findings were not considered toxicologically adverse.

Slight but statistically significant increases were observed in liver ALT and AST enzyme activities in the 300 (ALT) and 375 (ALT and AST) mg/kg bw/day groups. Similarly, the mean CREA concentrations were slightly elevated in male treated animals. These slight, apparently dose-dependent changes may be indicative of a test article effect on hepatic and renal function; however, there were no related histopathological changes in the kidneys or livers of these animals to substantiate their relevance, and the values all remained well within historically normal ranges.

Interestingly, at lower doses in mice, theacrine (up to $30 \mathrm{mg} / \mathrm{kg}$ bw/day for seven days) was reported to protect against increases in ALT and AST levels induced by restraint stress [17]. Yet, in another recently published 90-day study, Crl: Sprague Dawley CD IGS rats given $150 \mathrm{mg} / \mathrm{kg}$ bw/day of the structurally similar compound, caffeine, also showed 
TABLE 2: Summary of notable histopathology findings.

\begin{tabular}{|c|c|c|c|c|c|c|c|c|c|c|c|}
\hline \multirow{3}{*}{ Organs } & \multirow{3}{*}{ Observations ${ }^{*}$} & \multicolumn{5}{|c|}{$\begin{array}{l}\text { Incidence of observations per group } \\
\text { Dose groups }(\mathrm{mg} / \mathrm{kd} \mathrm{bw} / \mathrm{d})\end{array}$} & \multicolumn{5}{|c|}{$\begin{array}{c}\text { Incidence of observations per group } \\
\text { Dose groups }(\mathrm{mg} / \mathrm{kd} \mathrm{bw} / \mathrm{d})\end{array}$} \\
\hline & & \multirow{2}{*}{ Control } & \multirow{2}{*}{180} & \multirow{2}{*}{300} & \multicolumn{2}{|c|}{375} & \multirow{2}{*}{ Control } & \multirow{2}{*}{180} & \multicolumn{2}{|c|}{300} & \multirow{2}{*}{375} \\
\hline & & & & & Survivors & Died early & & & Survivors & Died early & \\
\hline \multirow{3}{*}{ Epididymides } & & & & Males & & & & & Females & & \\
\hline & $\begin{array}{c}\text { Decreased } \\
\text { amount of } \\
\text { spermatozoa }\end{array}$ & $0 / 10$ & $0 / 10$ & $1 / 10$ & $1 / 9$ & $1 / 1$ & I & l & I & l & I \\
\hline & $\begin{array}{c}\text { Lack of } \\
\text { spermatozoa }\end{array}$ & $0 / 10$ & $0 / 10$ & $2 / 10$ & $8 / 9$ & $0 / 1$ & I & I & I & l & I \\
\hline Testes & $\begin{array}{c}\text { Decreased } \\
\text { intensity of } \\
\text { spermatogenesis }\end{array}$ & $0 / 10$ & $0 / 10$ & $5 / 10$ & $9 / 9$ & $1 / 1$ & I & I & I & I & l \\
\hline \multirow{2}{*}{ Liver } & Congestion & $0 / 10$ & I & I & $0 / 9$ & $1 / 1$ & $0 / 10$ & l & I & $2 / 2$ & $0 / 10$ \\
\hline & $\begin{array}{l}\text { Centrilobular } \\
\text { necrosis }\end{array}$ & $0 / 10$ & I & l & $0 / 9$ & $1 / 1$ & $0 / 10$ & I & l & $2 / 2$ & $0 / 10$ \\
\hline \multirow{3}{*}{ Lungs } & $\begin{array}{l}\text { Alveolar } \\
\text { emphysema }\end{array}$ & $2 / 10$ & I & I & $1 / 9$ & $1 / 1$ & $2 / 10$ & I & I & $2 / 2$ & $2 / 10$ \\
\hline & $\begin{array}{l}\text { Hyperplasia of } \\
\text { BALT }\end{array}$ & $2 / 10$ & I & I & $1 / 9$ & $0 / 1$ & $1 / 10$ & I & I & $0 / 2$ & $0 / 10$ \\
\hline & Congestion & $0 / 10$ & l & l & $0 / 9$ & $1 / 1$ & $0 / 10$ & l & I & $2 / 2$ & $0 / 10$ \\
\hline Prostate & $\begin{array}{l}\text { Decreased } \\
\text { amount of } \\
\text { secretion }\end{array}$ & $0 / 10$ & I & I & $3 / 9$ & $0 / 1$ & 1 & I & 1 & I & I \\
\hline Skin & $\begin{array}{l}\text { Exudative } \\
\text { dermatitis }\end{array}$ & $0 / 10$ & $1 / 1$ & $1 / 1$ & $2 / 9$ & $0 / 1$ & $0 / 10$ & $0 / 10$ & $0 / 10$ & $0 / 10$ & $0 / 10$ \\
\hline Uterus & Dilatation & 1 & 1 & 1 & 1 & 1 & $1 / 10$ & 1 & 1 & $0 / 2$ & $4 / 9$ \\
\hline
\end{tabular}

* Number of animals with observations/number of animals examined.

/, not examined; BALT, bronchus associated lymphoid tissue; $\mathrm{mg} / \mathrm{kg}$ bw/d, milligrams per kilogram body weight per day.

increases in AST, ALT, and CREA that fell within historical control ranges [32]. Significant differences in AST and ALT were reported in a National Toxicology Program study in Fischer 244 rats on caffeine at doses up to $287 \mathrm{mg} / \mathrm{kg}$ bw/day; however, no dose-related patterns were established [33]. Slight but significant increases in AST and ALT have also been reported in humans with consumption of coffee [34], although coffee/caffeine consumption has also been associated with protective effects against increases in liver enzymes (e.g., ALT) and liver protection in general [35-37]. Caffeine (and likely theacrine) is metabolized in the liver $[33,38]$ and thus high doses could theoretically have an effect on this organ due to high exposure chronically.

Other statistically significant differences in clinical chemistry values in various dose groups were slight and considered to be of little or no biological or toxicological relevance. For example, slight statistically significant differences in TBIL and $\mathrm{K}^{+}$, as compared to controls, occurred only in one gender, were not dose-dependent, and remained well within the historical control ranges. GLUC and $\mathrm{Na}^{+}$values appeared to decrease statistically significantly and dose-dependently in both genders suggesting a possible test article effect, although all values remained well within historical control ranges. Differences in $\mathrm{Cl}^{-}$and $\mathrm{Pi}$ did not show clear dose-response relationships.
Of note with regard to macroscopic findings (Table 1), smaller than normal testes (4/10 and 9/9) and epididymides $(4 / 10$ and 9/9) were observed in males of the 300 and $375 \mathrm{mg} / \mathrm{kg}$ bw/day groups, respectively. Three animals in the $375 \mathrm{mg} / \mathrm{kg}$ bw/day group also had smaller than normal prostates. Pale adrenal glands were observed in male animals at $300 \mathrm{mg} / \mathrm{kg}$ bw/day $(2 / 10)$ and in male and female animals at $375 \mathrm{mg} / \mathrm{kg}$ bw/day (7/9 and 4/10, resp.). Other minor necropsy findings shown in Table 1 (e.g., white compact formation on the surface of the kidney, scarring, and alopecia in several groups) were considered to be individual findings in male animals as they are common observations in untreated experimental rats of this strain and age.

Decreased organ weights compared to controls were observed in male animals in the testes of the 300 (absolute and relative to brain weight) and 375 (absolute and relative to body and brain weights) $\mathrm{mg} / \mathrm{kg}$ bw/day groups and epididymides of the 300 and 375 (absolute and relative to body and brain weights) $\mathrm{mg} / \mathrm{kg}$ bw/day groups. Increased weights compared to controls were noted for adrenal glands in males at 375 (absolute and relative to body and brain weight) and $300 \mathrm{mg} / \mathrm{kg}$ bw/day (relative to body weight only). Decreases in thymus weight (absolute and relative to body and brain weight) were noted at 300 and $375 \mathrm{mg} / \mathrm{kg}$ bw/day in both male and female animals (Tables 9-11). Statistically significant 


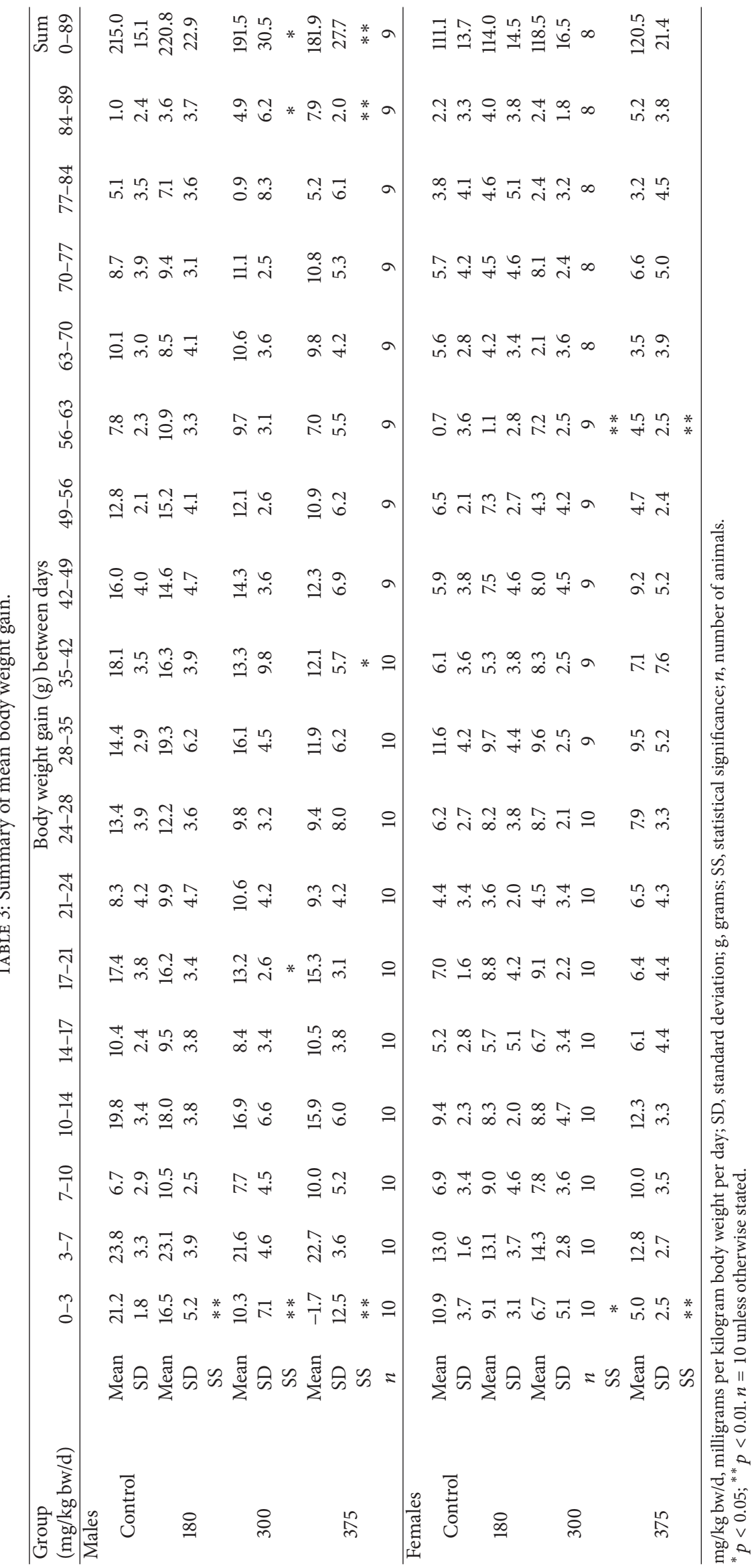




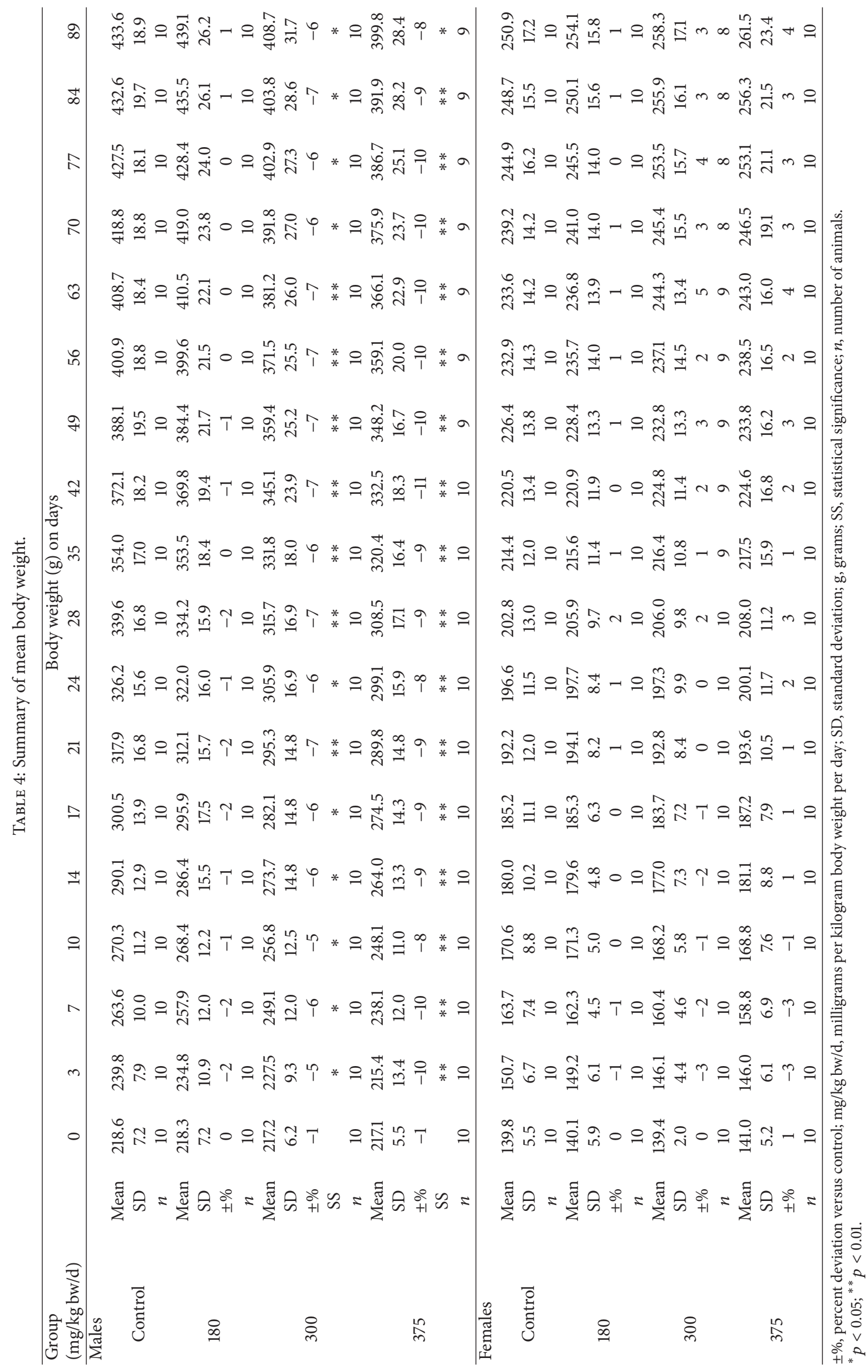


TABle 5: Summary of food consumption.

\begin{tabular}{|c|c|c|c|c|c|c|c|c|c|c|c|c|c|c|}
\hline \multirow{2}{*}{$\begin{array}{l}\text { Group } \\
(\mathrm{mg} / \mathrm{kg} \text { bw/d) }\end{array}$} & & \multicolumn{13}{|c|}{ Daily mean food consumption (g/animal/day) on weeks } \\
\hline & & 1 & 2 & 3 & 4 & 5 & 6 & 7 & 8 & 9 & 10 & 11 & 12 & 13 \\
\hline \multicolumn{15}{|l|}{ Males } \\
\hline \multirow{2}{*}{ Control } & Mean & 25.0 & 25.2 & 26.4 & 26.9 & 25.8 & 25.9 & 26.9 & 25.7 & 24.2 & 25.3 & 23.8 & 25.4 & 24.1 \\
\hline & $\mathrm{SD}$ & 1.56 & 1.76 & 1.93 & 1.74 & 2.13 & 1.94 & 2.25 & 1.87 & 2.04 & 2.50 & 2.03 & 2.31 & 2.47 \\
\hline \multirow{4}{*}{180} & Mean & 23.1 & 25.3 & 26.6 & 27.2 & 27.1 & 26.8 & 26.9 & 26.1 & 25.3 & 26.7 & 25.3 & 26.2 & 26.5 \\
\hline & SD & 1.52 & 1.70 & 2.13 & 1.82 & 1.88 & 2.16 & 2.27 & 2.24 & 1.88 & 1.65 & 1.45 & 1.59 & 1.84 \\
\hline & $\pm \%$ & -7.7 & 0.4 & 0.9 & 1.1 & 5.1 & 3.3 & 0.1 & 1.7 & 4.8 & 5.9 & 6.3 & 3.2 & 10.2 \\
\hline & SS & $*$ & & & & & & & & & & & & $*$ \\
\hline \multirow{4}{*}{300} & Mean & 21.0 & 23.6 & 23.6 & 24.9 & 24.5 & 24.4 & 24.9 & 23.9 & 23.7 & 24.8 & 23.7 & 24.1 & 24.1 \\
\hline & SD & 1.72 & 1.43 & 2.52 & 1.22 & 1.16 & 1.40 & 1.69 & 1.47 & 1.40 & 1.23 & 1.47 & 1.93 & 2.21 \\
\hline & $\pm \%$ & -16 & -6 & -11 & -7 & -5 & -6 & -7 & -7 & -2 & -2 & 0 & -5 & 0 \\
\hline & SS & $* *$ & & $* *$ & $* *$ & & & $*$ & $*$ & & & & & \\
\hline \multirow{5}{*}{375} & Mean & 18.2 & 22.8 & 24.4 & 24.7 & 23.2 & 23.2 & 24.4 & 23.2 & 22.6 & 23.8 & 23.2 & 24.6 & 24.7 \\
\hline & $\mathrm{SD}$ & 2.76 & 2.48 & 1.62 & 1.43 & 1.86 & 1.71 & 1.54 & 1.94 & 1.86 & 2.04 & 2.15 & 2.76 & 2.21 \\
\hline & $n$ & 10 & 10 & 10 & 10 & 10 & 10 & 9 & 9 & 9 & 9 & 9 & 9 & 9 \\
\hline & $\pm \%$ & -27 & -10 & -8 & -8 & -10 & -11 & -9 & -9 & -7 & -6 & -2 & -3 & 3 \\
\hline & SS & $* *$ & $* *$ & $*$ & $* *$ & $* *$ & $* *$ & $*$ & $*$ & & & & & \\
\hline \multicolumn{15}{|l|}{ Females } \\
\hline \multirow{2}{*}{ Control } & Mean & 17.3 & 17.6 & 17.8 & 18.9 & 19.5 & 19.3 & 19.7 & 19.0 & 17.9 & 19.4 & 18.6 & 20.5 & 20.0 \\
\hline & $\mathrm{SD}$ & 1.04 & 1.35 & 1.19 & 1.34 & 1.60 & 1.37 & 1.54 & 2.19 & 2.21 & 2.15 & 2.66 & 2.31 & 2.69 \\
\hline \multirow{5}{*}{180} & Mean & 15.5 & 17.0 & 17.8 & 18.2 & 18.3 & 18.4 & 19.3 & 17.9 & 17.3 & 18.8 & 17.6 & 19.2 & 19.4 \\
\hline & $\mathrm{SD}$ & 0.53 & 0.88 & 1.13 & 1.10 & 1.48 & 1.46 & 1.51 & 1.16 & 1.14 & 1.63 & 1.18 & 1.48 & 1.69 \\
\hline & $\pm \%$ & -10 & -4 & 0 & -4 & -6 & -5 & -2 & -6 & -3 & -3 & -5 & -6 & -3 \\
\hline & SS & $* *$ & & & & & & & & & & & & \\
\hline & & $* *$ & & & & & & & & & & & & \\
\hline \multirow{6}{*}{300} & Mean & 14.6 & 16.5 & 17.8 & 18.4 & 18.4 & 18.7 & 19.5 & 18.1 & 17.8 & 18.8 & 18.9 & 20.5 & 19.6 \\
\hline & $\mathrm{SD}$ & 1.81 & 1.13 & 1.41 & 1.12 & 1.39 & 0.98 & 1.61 & 1.46 & 1.03 & 0.68 & 2.83 & 3.47 & 1.18 \\
\hline & $n$ & 10 & 10 & 10 & 10 & 9 & 9 & 9 & 9 & 9 & 8 & 8 & 8 & 8 \\
\hline & $\pm \%$ & -15 & -6 & 0 & -3 & -6 & -3 & -1 & -5 & 0 & -3 & 2 & 0 & -2 \\
\hline & SS & $* *$ & & & & & & & & & & & & \\
\hline & & $* *$ & & & & & & & & & & & & \\
\hline \multirow{4}{*}{375} & Mean & 14.4 & 17.5 & 17.6 & 18.8 & 18.7 & 18.6 & 19.6 & 18.7 & 17.7 & 18.9 & 18.2 & 19.8 & 19.9 \\
\hline & SD & 1.49 & 1.08 & 2.14 & 1.17 & 1.80 & 2.26 & 1.57 & 1.55 & 1.45 & 1.64 & 1.79 & 1.91 & 1.95 \\
\hline & $\pm \%$ & -16.9 & -0.6 & -1.0 & -0.5 & -4.2 & -3.9 & -0.3 & -1.7 & -1.2 & -2.9 & -2.1 & -3.3 & -0.2 \\
\hline & SS & $* *$ & & & & & & & & & & & & \\
\hline
\end{tabular}

$\pm \%$, percent deviation versus control; $\mathrm{mg} / \mathrm{kg}$ bw/d, milligrams per kilogram body weight per day; SD, standard deviation; g, grams; SS, statistical significance; $n$, number of animals.

${ }^{*} p<0.05 ;{ }^{* *} p<0.01 . n=10$ unless otherwise stated.

differences in the weights of some organs in male animals (heart and kidneys) relative to body weight arose partially or fully from the body weight changes of these groups and were not seen in organ to brain weight ratios. Differences in some organ weights (absolute or relative) were observed only in the lower dose groups but not in the higher dose groups (liver, thyroid, and uterus) and, therefore, were not considered treatment-related.

In surviving animals, histological examination (Table 2) revealed decreased intensity of spermatogenesis in the seminiferous tubuli in all male animals at $375 \mathrm{mg} / \mathrm{kg}$ bw/day and in half of male animals at $300 \mathrm{mg} / \mathrm{kg}$ bw/day as compared to controls. In all animals with testicular findings, giant cells in the seminiferous tubuli were noted. Lack of mature spermatozoa in the ductuli of epididymides $(2 / 10$ at $300 \mathrm{mg} / \mathrm{kg}$ bw/day and $8 / 9$ at $375 \mathrm{mg} / \mathrm{kg}$ bw/day to a moderate or severe degree) and decreased number of mature spermatozoa $(1 / 10$ at $300 \mathrm{mg} / \mathrm{kg}$ bw/day and $1 / 9$ at $375 \mathrm{mg} / \mathrm{kg}$ bw/day in minimal or mild degree) were seen in male animals. The alterations in the testes and epididymides were not accompanied 
TABLE 6: Summary of feed efficiency.

\begin{tabular}{|c|c|c|c|c|c|c|c|c|c|c|c|c|c|c|c|}
\hline \multirow{3}{*}{$\begin{array}{l}\text { Group } \\
(\mathrm{mg} / \mathrm{kg} \text { bw/d) }\end{array}$} & & \multicolumn{13}{|c|}{ Feed efficiency (g bw/g food) } & \multirow{2}{*}{$\begin{array}{l}\text { Sum } \\
0-89\end{array}$} \\
\hline & Days & $0-7$ & $7-14$ & $14-21$ & $21-28$ & $28-35$ & $35-42$ & $42-49$ & $49-56$ & $56-63$ & $63-70$ & $70-77$ & $77-84$ & $84-89$ & \\
\hline & Weeks & 1 & 2 & 3 & 4 & 5 & 6 & 7 & 8 & 9 & 10 & 11 & 12 & 13 & $1-13$ \\
\hline \multicolumn{16}{|l|}{ Males } \\
\hline \multirow{2}{*}{ Control } & Mean & 0.26 & 0.15 & 0.15 & 0.12 & 0.08 & 0.10 & 0.09 & 0.07 & 0.05 & 0.06 & 0.05 & 0.03 & 0.02 & 0.10 \\
\hline & SD & 0.02 & 0.02 & 0.02 & 0.02 & 0.01 & 0.02 & 0.02 & 0.02 & 0.01 & 0.01 & 0.02 & 0.02 & 0.02 & 0.01 \\
\hline \multirow{3}{*}{180} & Mean & 0.24 & 0.16 & 0.14 & 0.12 & 0.10 & 0.09 & 0.08 & 0.08 & 0.06 & 0.04 & 0.05 & 0.04 & 0.04 & 0.09 \\
\hline & SD & 0.03 & 0.01 & 0.02 & 0.03 & 0.03 & 0.02 & 0.02 & 0.02 & 0.02 & 0.02 & 0.02 & 0.02 & 0.01 & 0.01 \\
\hline & SS & & & & & & & & & & & & & $*$ & \\
\hline \multirow{3}{*}{300} & Mean & 0.21 & 0.15 & 0.13 & 0.12 & 0.09 & 0.09 & 0.08 & 0.07 & 0.06 & 0.06 & 0.07 & 0.02 & 0.05 & 0.09 \\
\hline & $\mathrm{SD}$ & 0.05 & 0.05 & 0.03 & 0.03 & 0.02 & 0.02 & 0.02 & 0.01 & 0.02 & 0.02 & 0.02 & 0.02 & 0.04 & 0.01 \\
\hline & SS & * & & & & & & & & & & & & $*$ & \\
\hline \multirow{3}{*}{375} & Mean & 0.15 & 0.14 & 0.14 & 0.11 & 0.08 & 0.07 & 0.07 & 0.07 & 0.05 & 0.06 & 0.07 & 0.04 & 0.06 & 0.09 \\
\hline & SD & 0.08 & 0.07 & 0.05 & 0.05 & 0.03 & 0.03 & 0.04 & 0.04 & 0.03 & 0.02 & 0.03 & 0.02 & 0.02 & 0.01 \\
\hline & SS & $* *$ & & & & & $*$ & & & & & & & $* *$ & \\
\hline \multicolumn{16}{|l|}{ Females } \\
\hline \multirow{2}{*}{ Control } & Mean & 0.20 & 0.13 & 0.10 & 0.08 & 0.08 & 0.05 & 0.05 & 0.05 & 0.02 & 0.05 & 0.05 & 0.03 & 0.04 & 0.07 \\
\hline & SD & 0.02 & 0.02 & 0.02 & 0.03 & 0.03 & 0.02 & 0.02 & 0.02 & 0.02 & 0.01 & 0.03 & 0.02 & 0.02 & 0.01 \\
\hline \multirow{3}{*}{180} & Mean & 0.20 & 0.15 & 0.11 & 0.09 & 0.07 & 0.04 & 0.05 & 0.06 & 0.02 & 0.04 & 0.05 & 0.05 & 0.06 & 0.07 \\
\hline & SD & 0.04 & 0.04 & 0.04 & 0.03 & 0.03 & 0.03 & 0.03 & 0.02 & 0.01 & 0.02 & 0.02 & 0.03 & 0.03 & 0.01 \\
\hline & SS & & & & & & & & & & & & & & \\
\hline \multirow{3}{*}{300} & Mean & 0.20 & 0.14 & 0.13 & 0.10 & 0.07 & 0.06 & 0.06 & 0.04 & 0.06 & 0.02 & 0.06 & 0.03 & 0.03 & 0.07 \\
\hline & $\mathrm{SD}$ & 0.04 & 0.04 & 0.03 & 0.03 & 0.02 & 0.02 & 0.03 & 0.02 & 0.02 & 0.02 & 0.02 & 0.02 & 0.02 & 0.01 \\
\hline & SS & & & & & & & & & $* *$ & $*$ & & & & \\
\hline \multirow{3}{*}{375} & Mean & 0.18 & 0.18 & 0.10 & 0.11 & 0.08 & 0.07 & 0.07 & 0.04 & 0.04 & 0.04 & 0.06 & 0.04 & 0.07 & 0.07 \\
\hline & SD & 0.02 & 0.04 & 0.04 & 0.03 & 0.03 & 0.02 & 0.04 & 0.02 & 0.02 & 0.01 & 0.03 & 0.02 & 0.03 & 0.01 \\
\hline & SS & & $* *$ & & & & & & & & & & & & * \\
\hline
\end{tabular}

$\pm \%$, percent deviation versus control; $\mathrm{mg} / \mathrm{kg}$ bw/d, milligrams per kilogram body weight per day; $\mathrm{g}$ bw/g food, grams body weight per grams of food; SD, standard deviation; g, grams; SS, statistical significance; $n$, number of animals.

${ }^{*} p<0.05 ;{ }^{* *} p<0.01$.

by inflammation, degeneration, or necrosis. The number and cytomorphology of interstitial testicular cells were the same as in control male animals. A decreased amount of secretion in the tubuli of the prostate was observed in three male animals at $375 \mathrm{mg} / \mathrm{kg}$ bw/day. In the remaining male animals of the $300 \mathrm{mg} / \mathrm{kg}$ bw/day group (5/10) and in all animals of the $180 \mathrm{mg} / \mathrm{kg} \mathrm{bw} /$ day and control groups, the various spermatogenic cells (spermatogonia, spermatocytes, spermatids, and spermatozoa)-representing different phases in the development and differentiation of the spermatozoonsand the interstitial cells appeared normal. Similar effects have been reported in rats after consumption of high levels of the purine alkaloids theobromine and caffeine, namely, atrophy of the testes and epididymides and spermatogenic cell degeneration, although the mechanism by which this occurs is unknown $[39,40]$. However in human studies, caffeine intake has not been associated with adverse effects related to semen quality, and fertility levels have, overall, not consistently been linked to caffeine intake [41].

There were no other treatment-related findings upon microscopic examination of the selected tissues. Findings that were not considered toxicologically relevant occurred in a few animals; for example, slight, focal alveolar emphysema was observed in the lungs of some male and female animals in control and high-dose groups with similar incidence. This finding is connected to hypoxia, dyspnea, and circulatory disturbance that occurs during exsanguination and was considered unrelated to test article administration [42]. Hyperplasia of bronchus-associated lymphoid tissue (BALT) was also observed in both the control and high-dose groups (with greater incidence in the control group). This is a physiological, immunomorphological phenomenon $[43,44]$ and is not considered toxicologically relevant. Dilatation of the uterine horns occurred in female animals of control and high-dose groups; this is considered a slight neurohormonal phenomenon connected to the estrus phase of the inner genital organs and not toxicologically relevant [45].

No histopathological findings were noted in the adrenal or thymus glands. Thus the pale adrenals and differences in organ weights of the adrenals and thymus were considered likely to be an indication of the adaptive process (the response of the organ to environmental variation in order to maintain 


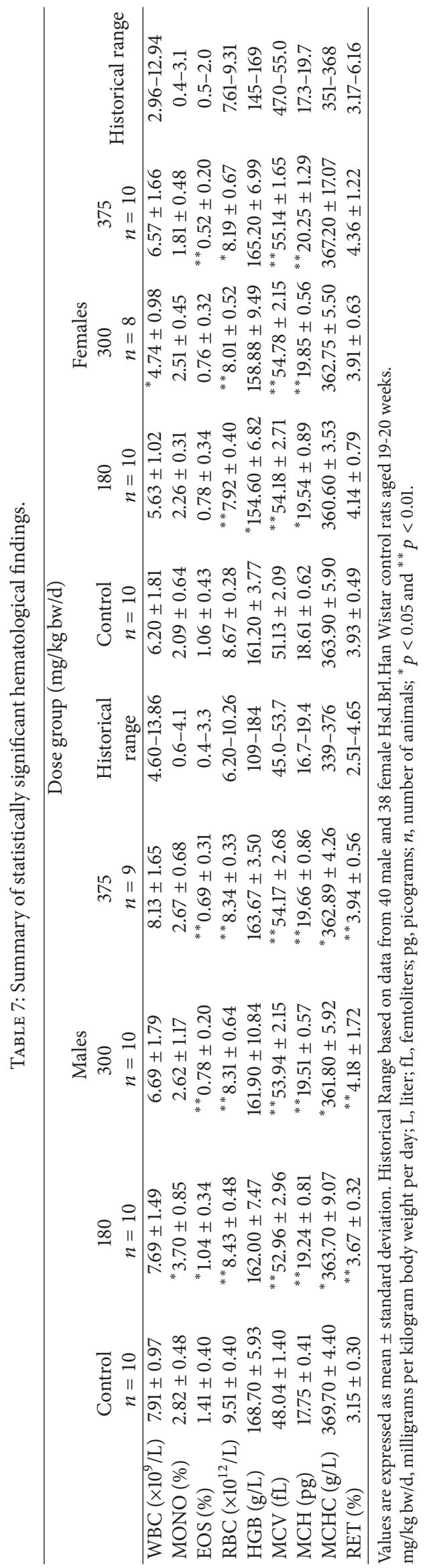




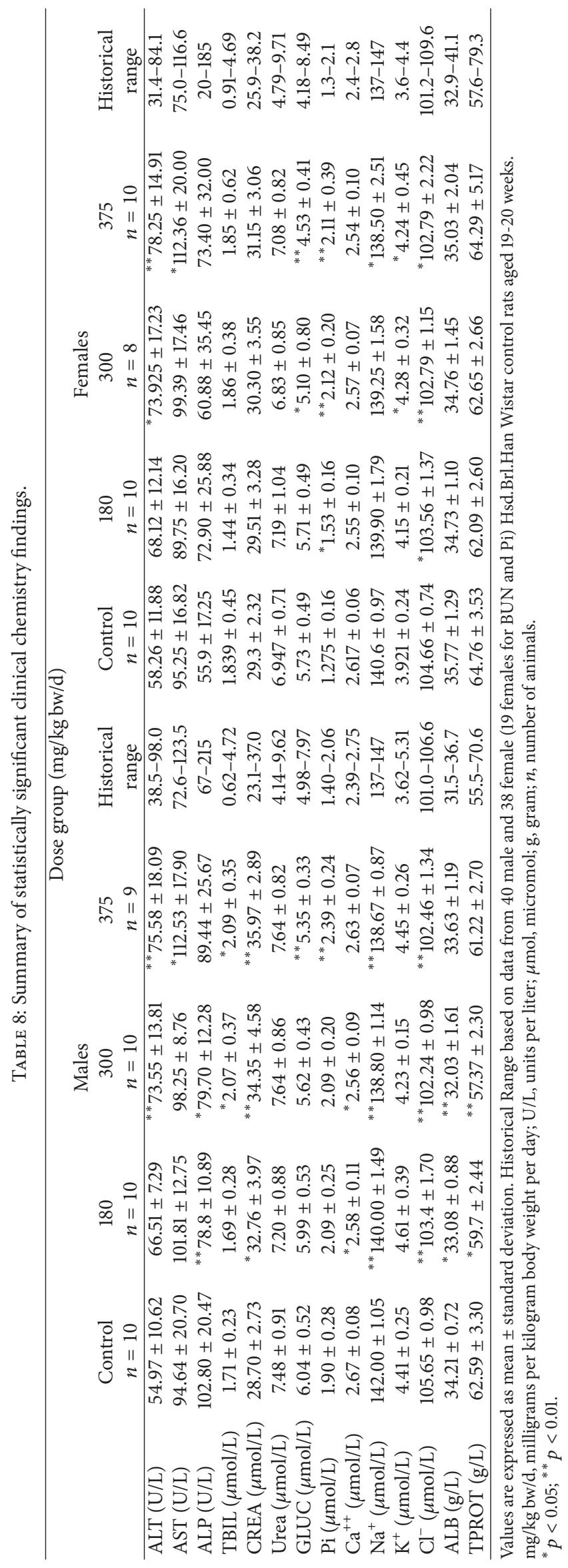




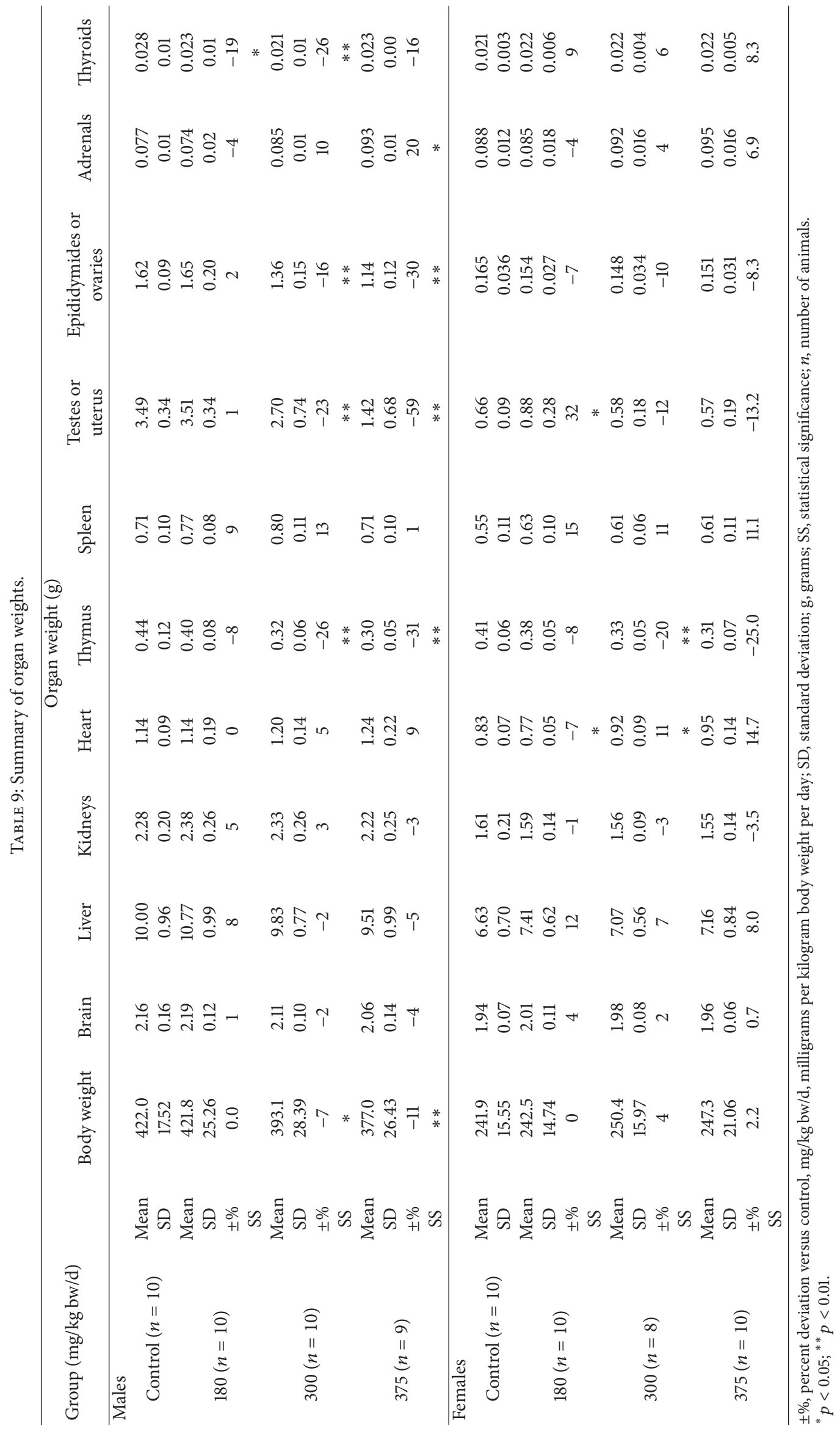




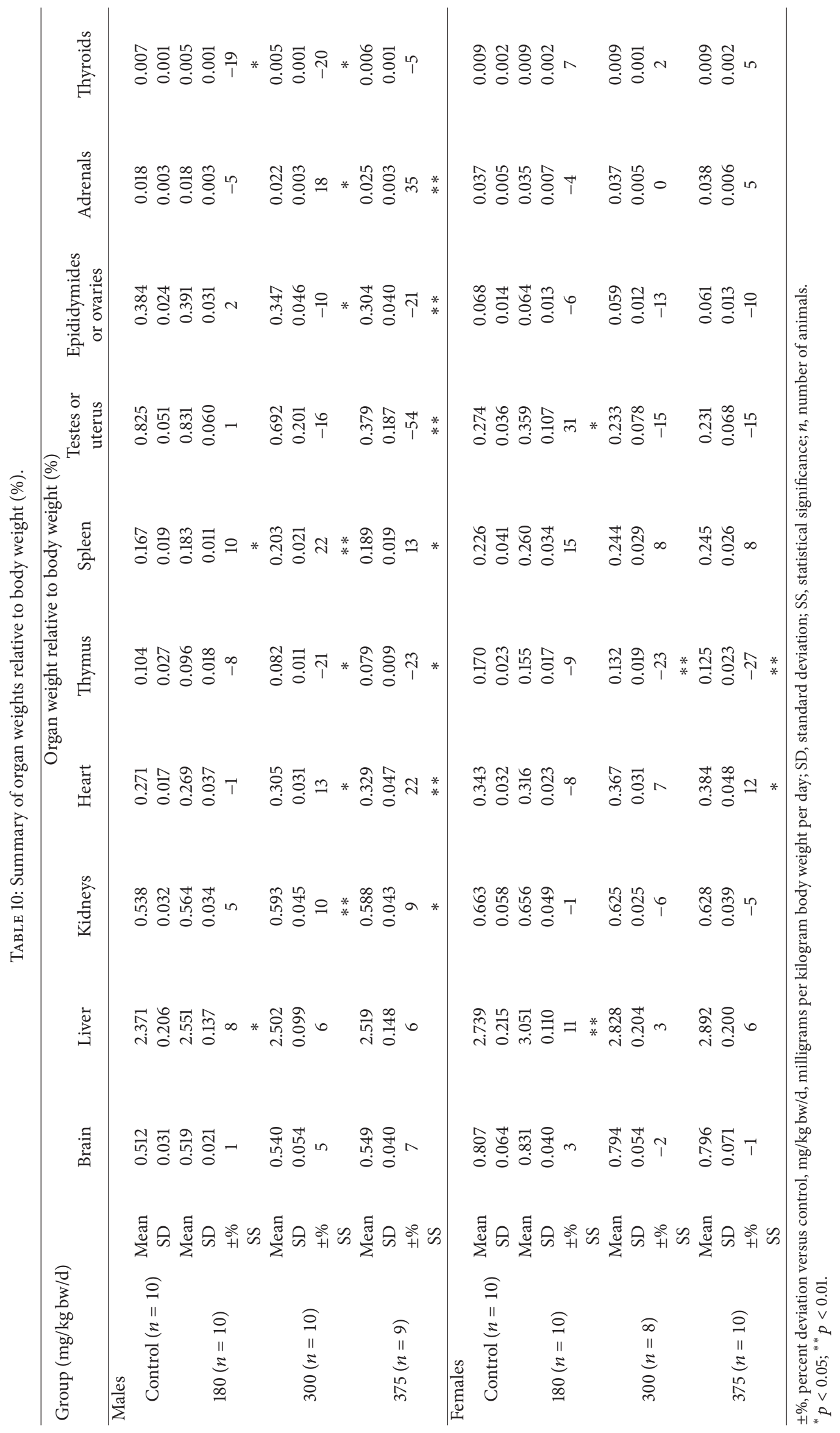




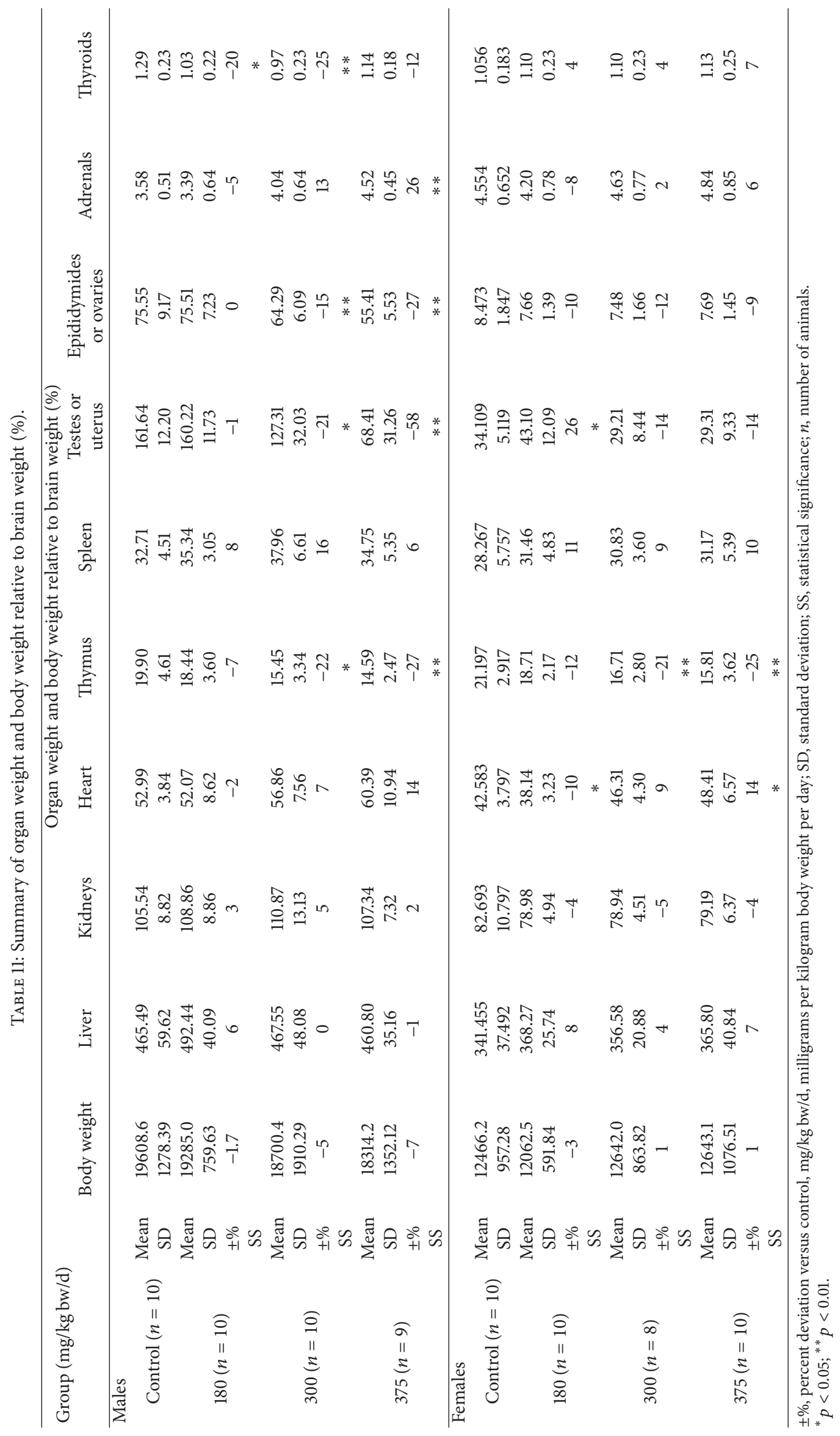


function/survival) or stress response, and the toxicological significance was considered equivocal as has also been seen with theobromine and caffeine consumption in rats [32, 39, $46,47]$.

\section{Conclusion}

In summary, doses of up to $300 \mathrm{mg}(3.8 \mathrm{mg} / \mathrm{kg}$ bw/day for a $78 \mathrm{~kg}$ human) given to healthy males and females in a previous clinical study did not result in any adverse effects or potential toxicological findings in numerous clinical safety markers [24]. In the present GLP and OECD 408 compliant toxicological study in Wistar rats, theacrine consumption was associated with mortality at $300 \mathrm{mg} / \mathrm{kg}$ bw/day in two of ten females and, at $375 \mathrm{mg} / \mathrm{kg}$ bw/day in one of ten males, with centrilobular hepatocellular necrosis considered the likely cause of death. Males in the $375 \mathrm{mg} / \mathrm{kg}$ bw/day group also had reductions in body weight gain, food consumption and feed efficiency, and decreased weight of the testes and epididymides, along with decreased intensity of spermatogenesis, amount of mature spermatozoa, and prostate secretions. Males of the $300 \mathrm{mg} / \mathrm{kg}$ bw/day similarly had decreased weight of testes and epididymides and decreased intensity of spermatogenesis and amount of mature spermatozoa. Based on observations made in this 90 -day repeated-dose gavage toxicity study and the lack of toxicologically relevant findings in the low dose group, the NOAEL for theacrine is considered to be $180 \mathrm{mg} / \mathrm{kg}$ bw/day in male and female Wistar rats.

\section{Competing Interests}

The authors declare that they have no competing interests.

\section{Acknowledgments}

The authors would like to thank the following participating investigators for their contributions to the work: Viktória Balogh, Erzsébet Biczó, Ibolya Bogdán, Monika Csatári, Tímea Csörge, Ildikó Hermann, Isvánné Horváth, Zoltán Jakab, Klára Fritz Kovácsné, Viktória Matina, Ágota Jó Schüllerné, János Stáhl, Beatrix Szilágyi Sümeginé, Éva Szabó, Ferenc Szabó, Zsuzsanna Szabó, Edit Szám, Judit Szilák, Márta Tenk, Zsuzsanna Vuleta, and Levente Zoltán for the performance of experimental tasks and/or collection of data and Jared Brodin for copyediting and administrative support in preparation of the paper. The authors disclose that financial support for the research described herein was provided by Compound Solutions Inc. (Carlsbad, CA).

\section{References}

[1] J. B. Petermann and T. W. Baumann, "Metabolic relations between methylxanthines and methyluric acids in Coffea L.," Plant Physiology, vol. 73, no. 4, pp. 961-964, 1983.

[2] H. Ashihara, M. Kato, and A. Crozier, "Distribution, biosynthesis and catabolism of methylxanthines in plants," in Methylxanthines, B. B. Fredholm, Ed., vol. 200 of Handbook of Experimental Pharmacology, pp. 11-31, 2011.
[3] K. Li, X. Shi, X. Yang, Y. Wang, C. Ye, and Z. Yang, "Antioxidative activities and the chemical constituents of two Chinese teas, Camellia kucha and C. ptilophylla," International Journal of Food Science and Technology, vol. 47, no. 5, pp. 1063-1071, 2012.

[4] A. L. Anaya, R. Cruz-Ortega, and G. R. Waller, "Metabolism and ecology of purine alkaloids," Frontiers in Bioscience, vol. 11, no. 1, pp. 2354-2370, 2006.

[5] T. Lim, "Theobroma grandiflorum," in Edible Medicinal and Non-Medicinal Plants: Volume 3, Fruits, pp. 252-258, Springer, New York, NY, USA, 2012.

[6] M. Vasconcelos, M. da Silva, J. Maia, and O. Gottlieb, "Estudo químico de sementes do cupuaçu," Acta Amazônica, vol. 5, no. 3, pp. 293-295, 1975.

[7] T. Baumann and H. Wanner, "The 1,3,7,9-tetramethyluric acid content of cupu (Theobroma grandiflorum Schum.)," Acta Amazônica, vol. 10, no. 2, p. 425, 1980.

[8] F. Marx and J. G. S. Maia, "Purine alkaloids in seeds of Theobroma species from the Amazon," Zeitschrift für LebensmittelUntersuchung und Forschung, vol. 193, no. 5, pp. 460-461, 1991.

[9] G. Xie, R.-R. He, X. Feng et al., "The hypoglycemic effects of Camellia assamica var. kucha extract," Bioscience, Biotechnology and Biochemistry, vol. 74, no. 2, pp. 405-407, 2010.

[10] S.-B. Li, Y.-F. Li, Z.-F. Mao et al., "Differing chemical compositions of three teas may explain their different effects on acute blood pressure in spontaneously hypertensive rats," Journal of the Science of Food and Agriculture, vol. 95, no. 6, pp. 1236-1242, 2015.

[11] X.-Q. Zheng, C.-X. Ye, M. Kato, A. Crozier, and H. Ashihara, "Theacrine (1,3,7,9-tetramethyluric acid) synthesis in leaves of a Chinese tea, kucha (Camellia assamica var. kucha)," Phytochemistry, vol. 60, no. 2, pp. 129-134, 2002.

[12] A. A. Feduccia, Y. Wang, J. A. Simms et al., "Locomotor activation by theacrine, a purine alkaloid structurally similar to caffeine: involvement of adenosine and dopamine receptors," Pharmacology Biochemistry and Behavior, vol. 102, no. 2, pp. 241-248, 2012.

[13] J.-K. Xu, H. Kurihara, L. Zhao, and X.-S. Yao, “Theacrine, a special purine alkaloid with sedative and hypnotic properties from Cammelia assamica var. kucha in mice," Journal of Asian Natural Products Research, vol. 9, no. 7, pp. 665-672, 2007.

[14] Y. Wang, X. Yang, X. Zheng, J. Li, C. Ye, and X. Song, "Theacrine, a purine alkaloid with anti-inflammatory and analgesic activities," Fitoterapia, vol. 81, no. 6, pp. 627-631, 2010.

[15] G. Xie, M. Wu, Y. Huang et al., "Experimental study of the acrine on antidepressant effects," Chinese Pharmacological Bulletin, vol. 9, 2009.

[16] Y.-F. Li, M. Chen, C. Wang et al., “Theacrine, a purine alkaloid derived from Camellia assamica var. kucha, ameliorates impairments in learning and memory caused by restraint-induced central fatigue," Journal of Functional Foods, vol. 16, pp. 472483, 2015.

[17] W.-X. Li, Y.-F. Li, Y.-J. Zhai, W.-M. Chen, H. Kurihara, and R.R. He, "Theacrine, a purine alkaloid obtained from Camellia assamica var. kucha, attenuates restraint stress-provoked liver damage in mice," Journal of Agricultural and Food Chemistry, vol. 61, no. 26, pp. 6328-6335, 2013.

[18] O. Cauli, A. Pinna, V. Valentini, and M. Morelli, "Subchronic caffeine exposure induces sensitization to caffeine and crosssensitization to amphetamine ipsilateral turning behavior independent from dopamine release," Neuropsychopharmacology, vol. 28, no. 10, pp. 1752-1759, 2003. 
[19] P. Svenningsson, G. G. Nomikos, and B. B. Fredholm, "The stimulatory action and the development of tolerance to caffeine is associated with alterations in gene expression in specific brain regions," The Journal of Neuroscience, vol. 19, no. 10, pp. 40114022, 1999.

[20] B. A. Kihlman, "1,3,7,9-Tetramethyluric acid-a chromosomedamaging agent occurring as a natural metabolite in certain caffeine-producing plants," Mutation Research/Reviews in Genetic Toxicology, vol. 39, no. 3-4, pp. 297-315, 1977.

[21] B. A. Kihlman and G. Odmark, "Deoxyribonucleic acid synthesis and the production of chromosomal aberrations by streptonigrin, 8-ethoxycaffeine and 1,3,7,9-tetramethyluric acid," Mutation Research-Fundamental and Molecular Mechanisms of Mutagenesis, vol. 2, no. 6, pp. 494-505, 1965.

[22] J. Endres, N. Deshmukh, R. Glavitis et al., "A comprehensive toxicological assessment of the purine alkaloid theacrine," The Toxicologist, Supplement to Toxicological Sciences, vol. 150, no. 1, 2016, Abstract \#1459.

[23] "Safety of Teacrine ${ }^{\mathrm{TM}}$, a non-habituating, naturally-occuring purine alkaloid over eight weeks of continuous use," in Proceedings of the Annual Meeting of the International Society of Sport Nutrition, S. Hayward, J. Mullins, S. Urbina et al., Eds., Austin, Tex, USA, 2015.

[24] L. Taylor, P. Mumford, M. Roberts et al., "Safety of TeaCrine ${ }^{\circledR}$, a non-habituating, naturally-occurring purine alkaloid over eight weeks of continuous use," Journal of the International Society of Sports Nutrition, vol. 13, article 2, 2016.

[25] S. M. Habowski, J. E. Sandrock, A. W. Kedia, and T. N. Ziegenfuss, "The effects of Teacrine ${ }^{\mathrm{TM}}$, a nature-identical purine alkaloid, on subjective measures of cognitive function, psychometric and hemodynamic indices in healthy humans: a randomized, double-blinded crossover pilot trial," Journal of the International Society of Sports Nutrition, vol. 11, no. 1, article P49, 2014.

[26] T. N. Ziegenfuss, S. M. Habowski, J. E. Sandrock, A. W. Kedia, C. M. Kerksick, and H. L. Lopez, "A two-part approach to examine the effects of theacrine (TeaCrine ${ }^{\circledR}$ ) supplementation on oxygen consumption, hemodynamic responses, and subjective measures of cognitive and psychometric parameters," Journal of Dietary Supplements, 2016.

[27] OECD, OECD 408. Guideline for the testing of chemicals: repeated dose 90-day oral toxicity study in rodents, Section 4, No. 408, adopted 21, pp. 1-10, September 1998.

[28] FDA and Redbook 2000, Toxicological Principles for the Safety Assessment of Food Ingredients. IV.C.4.a. Subchronic Toxicity Studies with Rodents, 2003.

[29] National Research Council, Guide for the Care and Use of Laboratory Animals, Committee for the Update of the Guide for the Care and Use of Laboratory Animals, Institute for Laboratory Animal Research, Division on Earth and Life Studies, National Research Council, Washington, DC, USA, 2011.

[30] S. Irwin, "Comprehensive observational assessment: Ia. A systematic, quantitative procedure for assessing the behavioral and physiologic state of the mouse," Psychopharmacologia, vol. 13, no. 3, pp. 222-257, 1968.

[31] S. Eustis, G. Boorman, T. Harada, and J. Popp, "Liver," in Pathology of the Fischer Rat Reference and Atlas, pp. 71-94, Academic Press, San Diego, Calif, USA, 1990.

[32] R. W. Kapp Jr., O. Mendes, S. Roy, R. S. McQuate, and R. Kraska, "General and genetic toxicology of guayusa concentrate (Ilex guayusa)," International Journal of Toxicology, vol. 35, no. 2, pp. 222-242, 2016.
[33] OECD SIDS, Cafeine, CAS: 58-08-2, UNEP Publications, Paris, France, 2002.

[34] A. J. Onuegbu, J. M. Olisekodiaka, O. E. Adebolu, A. Adesiyan, and O. E. Ayodele, "Coffee consumption could affect the activity of some liver enzymes and other biochemical parameters in healthy drinkers," Medical Principles and Practice, vol. 20, no. 6, pp. 514-518, 2011.

[35] A. A. Modi, J. J. Feld, Y. Park et al., "Increased caffeine consumption is associated with reduced hepatic fibrosis," Hepatology, vol. 51, no. 1, pp. 201-209, 2010.

[36] C. E. Ruhl and J. E. Everhart, "Coffee and caffeine consumption reduce the risk of elevated serum alanine aminotransferase activity in the United States," Gastroenterology, vol. 128, no. 1, pp. 24-32, 2005.

[37] C. E. Ruhl and J. E. Everhart, "Coffee and tea consumption are associated with a lower incidence of chronic liver disease in the United States," Gastroenterology, vol. 129, no. 6, pp. 1928-1936, 2005.

[38] EFSA, "Scientific opinion. Opinion on the safety of caffeine," The EFSA Journal, vol. 13, no. 5, 2015.

[39] J. H. Gans, "Comparative toxicities of dietary caffeine and theobromine in the rat," Food and Chemical Toxicology, vol. 22, no. 5, pp. 365-369, 1984.

[40] H. Funabashi, M. Fujioka, M. Kohchi, Y. Tateishi, and N. Matsuoka, "Collaborative work to evaluate toxicity on male reproductive organs by repeated dose studies in rats. 22) effects of 2- and 4-week administration of theobromine on the testis," Journal of Toxicological Sciences, vol. 25, pp. 211-221, 2000.

[41] J. D. Peck, A. Leviton, and L. D. Cowan, "A review of the epidemiologic evidence concerning the reproductive health effects of caffeine consumption: a 2000-2009 update," Food and Chemical Toxicology, vol. 48, no. 10, pp. 2549-2576, 2010.

[42] J. Vandenberghe, Life-Span Data and Historical Data in Carcinogenicity Testing in Wistar Rats Crl:(WI) BR. Addendum 5.8, Janssen Research Foundation, Department of Toxicology, Charles River Deutschland, Beerse, Belgium, 1990.

[43] G. Boorman and S. Eustis, "Lung," in Pathology of the Fischer Rat: Reference and Atlas, G. Boorman, S. Eustis, M. Elwell, and W. MacKenzie, Eds., pp. 339-367, Academic Press, San Diego, Calif, USA, 1990.

[44] W. Haschek, C. Rousseaux, and M. Wallig, "Respiratory system. Structure and cell biology. Physiology and functional considerations-lymphoid tissue," in Fundamentals of Toxicologic Pathology, p. 98, Elsevier, New York, NY, USA, 2009.

[45] J. Vidal, M. Mirsky, K. Colman, K. Whitney, and D. Creasy, "Reproductive system and mammary gland," in Toxicologic Pathology Nonclinical Safety Assessment, chapter 18, pp. 717-830, CRC Press, Boca Raton, Fla, USA, 2013.

[46] M. Hamlin and D. Banas, "Adrenal gland," in Pathology of the Fischer rat Reference and Atlas, pp. 501-518, Academic Press, San Diego, Calif, USA, 1990.

[47] N. E. Everds, P. W. Snyder, K. L. Bailey et al., "Interpreting stress responses during routine toxicity studies: a review of the biology, impact, and assessment," Toxicologic Pathology, vol. 41, no. 4, pp. 560-614, 2013. 

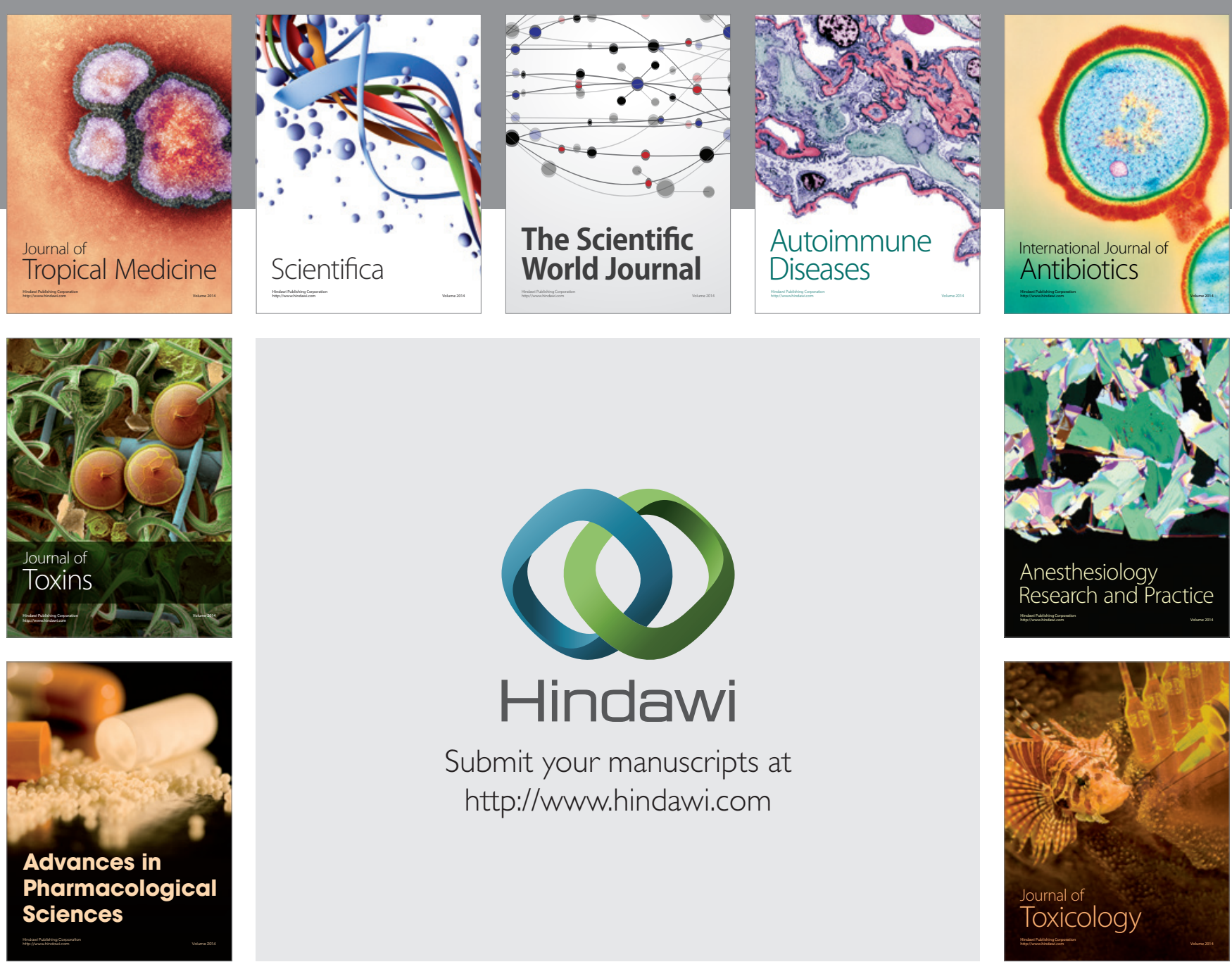

\section{Hindawi}

Submit your manuscripts at

http://www.hindawi.com
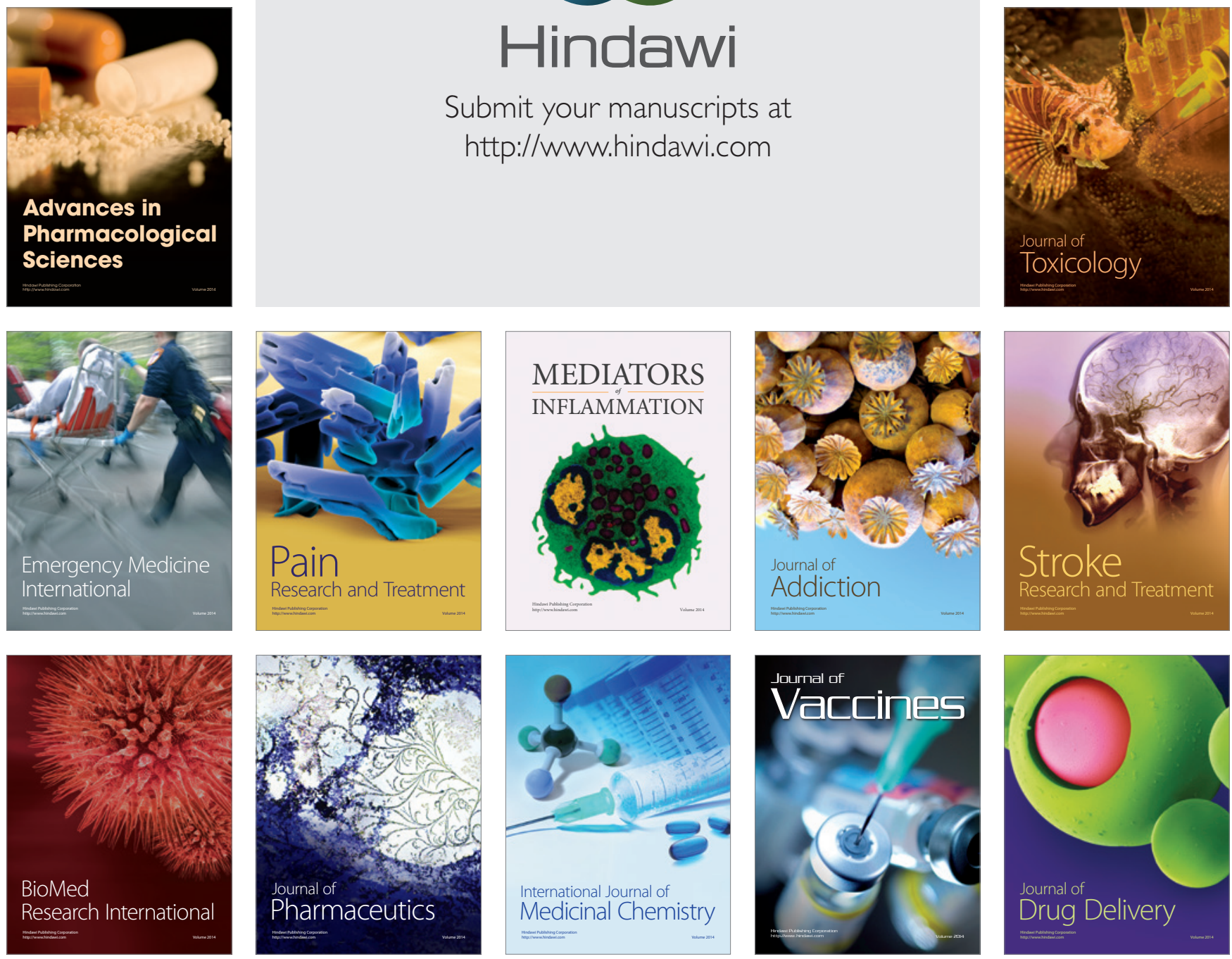